\title{
EVALUATION OF FIRE RESISTANCE OF FIRE PROTECTED STEEL STRUCTURES BY CALCULATION AND EXPERIMENTAL METHOD
}

\author{
A. Kovalov ${ }^{1}$, Y. Otrosh ${ }^{1}$, V. Tomenko ${ }^{2}$, V. Slovinskyi ${ }^{3}$ \\ ${ }^{I}$ National University of Civil Defence of Ukraine \\ ${ }^{2}$ Cherkasy Institute of Fire Safety of National University of Civil Defence of Ukraine \\ ${ }^{3}$ Cherkasy Scientific Research Forensic Centre of the Ministry of Internal Affairs in Ukraine
}

\begin{abstract}
Based on the developed geometric, physical, computer and finite element model, the fire resistance of fire-resistant steel structures was evaluated by calculation and experimental method. The adequacy of the developed computational-experimental method for assessing the fire resistance of fire-resistant steel structures in assessing the fire resistance of a fire-resistant I-beam steel column was verified. The results of tests for fire resistance of steel columns with fire-retardant coating at standard temperature of the fire without the load applied to them (temperature in the furnace, temperature in certain places on the surface of fire-retardant steel columns, the behavior of the investigated fireretardant coating). The analysis of tests on fire resistance of fire-resistant steel columns exposed to fire at standard temperature (temperature in the furnace, temperature in places of measurement of temperature on a surface of columns, behavior of a fire-retardant covering) is carried out. A computer model of the «steel column - reactive flame retardant coating» system has been built for numerical simulation of non-stationary heating of such a system. Simulation of non-stationary heating of the system «steel column - fire-retardant coating» in the software package FRIEND with the specified parameters (geometric model, thermal effects, initial and boundary conditions, properties of system materials). The reliability of the results of numerical modeling with real experimental data on the duration of fire exposure at the standard temperature of the fire to reach the critical temperature of steel. Based on the comparison of experimental results and numerical simulations, a conclusion is made about the adequacy of the developed model to the real processes that occur when heating fireretardant steel columns without applying a load under fire conditions at standard fire temperature. The efficiency of the proposed calculation and experimental method for assessing the fire resistance of fire-resistant steel structures has been confirmed.
\end{abstract}

Keywords: fire resistance, method of fire resistance assessment, fire protection, fire protection ability, fire protective coatings, steel structures.

\section{ОЦІНЮВАННЯ ВОГНЕСТІЙКОСТІ ВОГНЕЗАХИЩЕНИХ СТАЛЕВИХ КОНСТРУКЦЙ РОЗРАХУНКОВО- ЕКСПЕРИМЕНТАЛЬНИМ МЕТОДОМ}

\author{
Ковальов А. І. ${ }^{1}$, Отрош Ю. А. ${ }^{1}$, Томенко В. I. ${ }^{2}$, Словінський В. К. ${ }^{3}$ \\ ${ }^{1}$ Національний університет ичивільного захисту Украӥни \\ ${ }^{2}$ Черкаський інститут пожежної безпеки ім. Героїв Чорнобиля НУЦЗ Украйни \\ ${ }^{3}$ Черкаський науково-дослідний експертно-криміналістичний центр МВС України
}

Анотація: На основі розроблених геометричної, фізичної, комп'ютерної та скінченноелементної моделі здійснено оцінювання вогнестійкості вогнезахищених сталевих конструкцій розрахунково-експериментальним методом. Проведено перевірку адекватності розробленого розрахунково-експериментального методу оцінювання вогнестійкості вогнезахищених сталевих конструкцій при оцінюванні вогнестійкості вогнезахищеної двотаврової сталевої колони. Представлено результати випробувань на вогнестійкість сталевих колон 3 вогнезахисним покриттям при стандартному температурному режимові пожежі без 
прикладеного до них навантаження (температура в печі, температура у визначених місцях на поверхні вогнезахищених сталевих колон, поведінка досліджуваного вогнезахисного покриття). Проведено аналіз випробувань на вогнестійкість вогнезахищених сталевих колон, що піддавалися впливу пожежі за стандартним температурним режимом (температура в печі, температура у місцях вимірювання температури на поверхні колон, поведінка вогнезахисного покриття). Побудовано комп'ютерну модель системи «сталева колона -реактивне вогнезахисне покриття» для чисельного моделювання нестаціонарного прогріву такої системи. Проведено моделювання нестаціонарного прогріву системи «сталева колона - вогнезахисне покриття» в програмному комплексі FRIEND 3 заданими параметрами (геометрична модель, теплові впливи, початкові та граничні умови, властивості матеріалів системи). Проведено оцінку достовірності результатів чисельного моделювання з реальними експериментальними даними щодо тривалості вогневого впливу за стандартним температурним режимом пожежі до досягнення критичної температури сталі. На основі порівняння результатів експерименту та чисельного моделювання зроблено висновок про адекватність розробленої моделі реальним процесам, що відбуваються при нагріванні вогнезахищених сталевих колон без прикладення навантаження в умовах вогневого впливу за стандартного температурного режиму пожежі. Підтверджена працездатність запропонованого розрахунково-експериментального методу оцінювання вогнестійкості вогнезахищених сталевих конструкцій.

Ключові слова: вогнестійкість, метод оцінювання вогнестійкості, вогнезахист, вогнезахисна здатність, вогнезахисні покриття, сталеві конструкції. 


\section{INTRODUCTION}

Despite technical advances in construction and fire-fighting technologies, the latter has not become less dangerous. Fires claim thousands of lives and cause billions in damage. About $51 \%$ of all fires in the world occur in buildings and structures and transport. At the same time, $90 \%$ of all fire victims die on the premises.

These factors create a need to protect people from the impact of the identified threats. One of the most dangerous factors is fires in buildings and structures. Ensuring the safety of people and property must be performed taking into account all stages of the life cycle of facilities, such as scientific support and monitoring, design, construction, operation, as well as to exclude fires. Preventing the occurrence of fire allows technical means and organizational measures, in which the probability of occurrence and development of fire does not exceed the standard allowable value. The condition for reducing the irreversible consequences of fires at various facilities is the preservation of the bearing capacity of buildings, structures of technological structures and communications.

These stability requirements are provided by a set of measures provided for both production technology and the use of effective fire-retardant coatings for fire protection of building structures.

Therefore, in the context of globalization and increasing threats to humans, the first place is played by maintaining the resilience of buildings and structures in the event of fires and other natural disasters, as well as preserving their functional purpose after such impacts.

\section{ANALYSIS OF LITERATURE DATA AND PROBLEM STATEMENT}

Many well-known scientists have dealt with the issues of fire resistance assessment of fire-resistant steel structures. In [1], the authors developed two models of steel beams using ANSYS and OpenSEES programs, which take into account the constant mechanical load and the influence of fire temperature but do not take into account the presence of fire protection systems and their impact on modelling accuracy. The authors in [2] propose to use in the calculation of the temperature of fire-resistant steel structures in case of a fire a constant value of the thermal conductivity of the reactive fire-retardant coating, as it does not affect the accuracy of the calculations. However, as is known, the greatest accuracy of calculations is at the value of the thermal conductivity of the fire-retardant coating, which depends on the temperature. In [3] the results of the test for fire resistance of unprotected steel beams in comparison with simple and improved calculation methods given in EN 1993-1-2 are presented. The results showed the difference between the experimental and calculated temperature values obtained by FEM analysis. [4] presents a method for assessing the fire resistance of fire-resistant reactive fire-retardant coatings of steel structures. The method can be used to predict the behaviour of fire-retardant steel structures in different conditions (change in the coefficient of a cross-section of steel, coating thickness and type of fire exposure). However, there are no reliable data on the versatility of the method, including for passive fire-retardant coatings and the influence of climatic factors. In [5] experimental and calculated data on the determination of the temperature of steel plates with a fire-retardant covering in the conditions of fire influence on a standard fire have resulted. The authors analyze the possibility of using samples of reduced size and shape other than the size and shape of standardized samples of steel structures to assess the fire resistance of fire-resistant steel structures. In [6] we consider the results of experimental tests of steel plates of different sizes with water-based flame retardant coating, aimed at studying the thermal properties and the ratio of temperature and thickness of the coating in tests of steel plates of different thicknesses at standard temperature or slow-moving fire. However, the issues of the influence 
of fire temperature regimes on the accuracy of fire resistance assessment of fire-resistant steel structures have not been fully investigated.

The conducted analysis allows to state the tendency to spread the application of the calculation-experimental method for estimating the limits of fire resistance of fire-resistant steel building structures and fire-retardant ability of coatings for such structures. This method allows taking into account the values of thermophysical characteristics of fire-retardant coatings not only as constant values but also as a function of temperature. This allows to increase the accuracy of the method and take into account the processes of heat transfer in the fire-resistant steel structure under the influence of different temperature regimes of fire.

Thus, the unsolved part of the problem is the lack of effective methods for assessing the fire resistance of fire-resistant steel building structures with scientifically sound parameters of fire protection systems in the form of both reactive and passive fire-retardant coatings. Solving this problem will increase the accuracy of estimating fire-resistant steel structures with sufficient accuracy for engineering calculations using the results of fire resistance tests, which are fully correlated with the results of numerical simulations in modern software packages.

\section{THE PURPOSE AND OBJECTIVES OF THE STUDY}

The work aims to assess the fire resistance of fire-resistant steel structures using the developed calculation and experimental method.

To achieve this goal needed to solve the following tasks:

- to analyze the results of tests for fire resistance of 2 fire-retardant steel columns;

- to build a physical, geometric, computer model of non-stationary heating of a fireretardant steel column, in which to take into account and build:

- the geometry of the object under study;

- finite element model;

- thermal effects on the structure;

- choose the calculation algorithm for processing the obtained experimental data.

\section{ANALYSIS OF FIRE RESISTANCE TEST RESULTS}

The test was subjected to 2 steel columns of I-beam section HEB 200 (thickness 6.1 $\mathrm{mm}$ ), height $2 \mathrm{~m}$. The columns were treated with flame retardant "Amotherm Steel $\mathrm{Wb}$ " after the pre-application of soil GF-021. Three thermocouples were placed on each sample according to [7], as shown in Fig. 1.
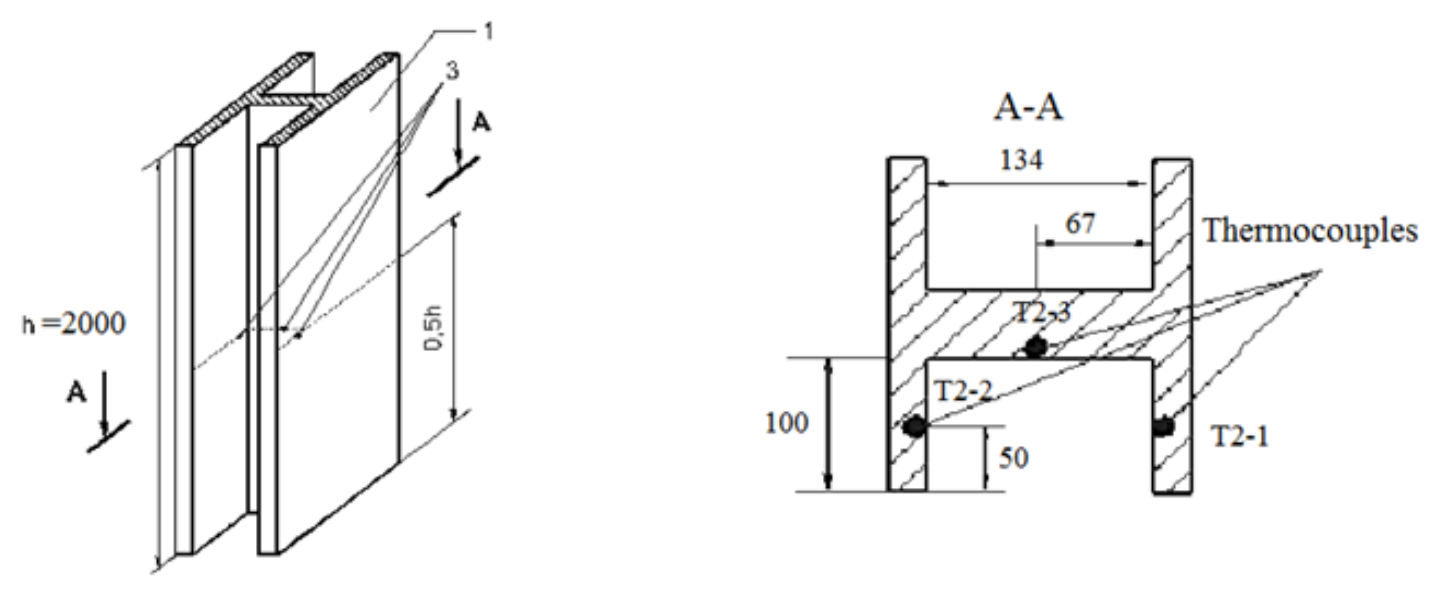

Fig. 1. Diagram of the location of thermocouples on samples of columns that are tested without load 
The flame retardant was applied by mechanization and manually. The average coating thickness was $2.927 \mathrm{~mm}$. The experiment was performed at an air temperature of $27^{\circ} \mathrm{C}$, relative humidity of $54 \%$. The average thickness of the coating of flame retardant "Amotherm Steel Wb" was (dry state without soil) $2.928 \mathrm{~mm}$ on the sample № 1 and $2.925 \mathrm{~mm}$ - on the sample № 2. Fig. 2 shows the types of samples in the furnace before (a) and after (b) the tests.

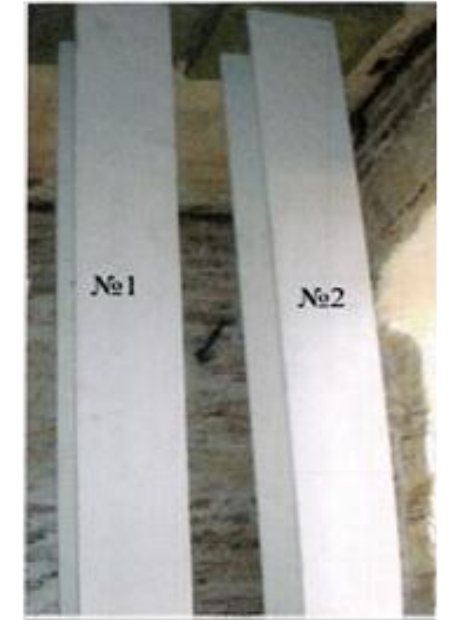

$a$

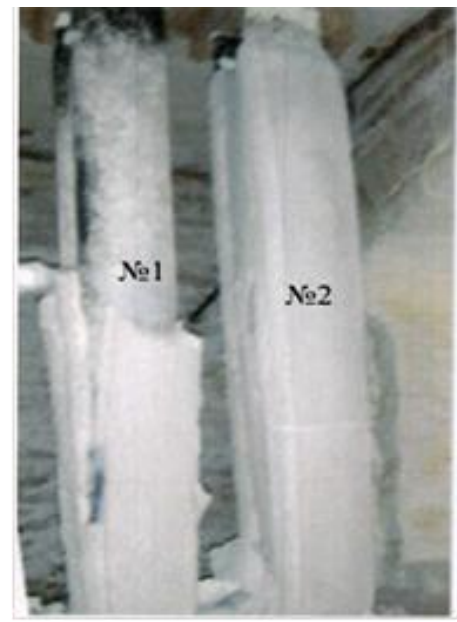

$b$

Fig. 2. Types of samples in the furnace before (a) and after (b) the tests

A special test furnace and metrological calibrated measuring equipment were used for the tests.

The temperature of the fire was determined by the formula:

$\Theta_{g}=20+345 \lg (8 t+1)$,

where $\Theta \mathrm{g}$ - the temperature of the gas environment in the fire compartment, ${ }^{\circ} \mathrm{C} ; t-$ time, $\min$.

The temperature in the furnace was reproduced according to the standard temperature of the fire (Fig. 3).

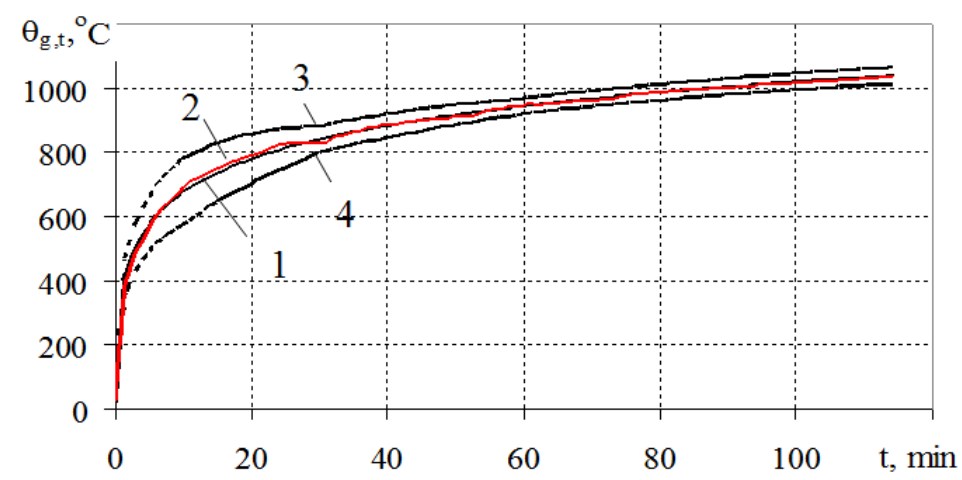

Fig. 3. Dependence of temperature in the furnace on the duration of fire influence: 1 - a curve of a standard temperature mode, 2 - a real curve of change of temperature in the furnace; 3 - the maximum values of temperature in the furnace are admissible at tests; 4 - the minimum values of temperature in the furnace are admissible attests

The volume swelling coefficient of the Amotherm Steel Web coating was $38.3 \mathrm{~cm}^{3} / \mathrm{g}$ (conditional linear swelling factor 47.9).

The dependence of the average temperatures of the samples of steel columns with the investigated fire-retardant coating on the time of fire exposure to the standard temperature of the fire is shown in Fig. 4. 


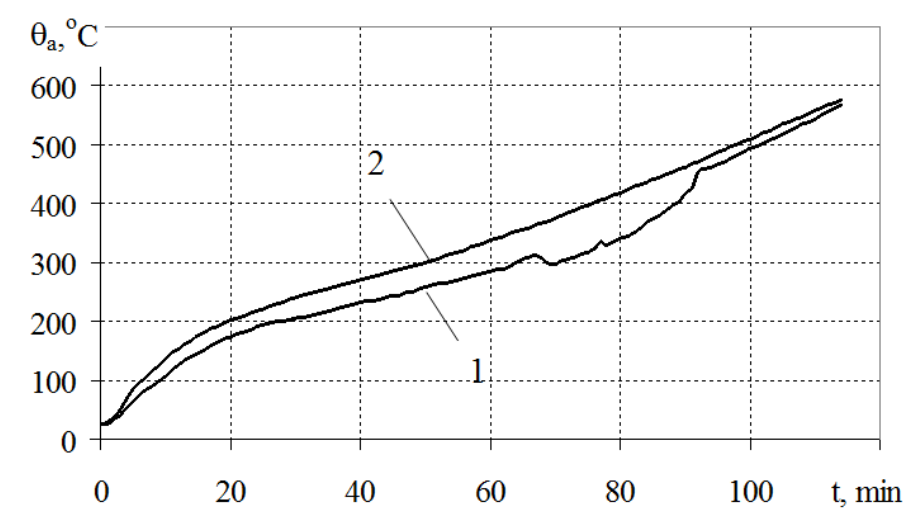

Fig. 4. Dependence of average temperatures of samples of fire-retardant steel columns on the time of fire exposure according to the standard temperature of the fire: 1 - sample column № $1 ; 2$ - sample column № 2

As shown in Fig. 4 temperature dependences were compared with the results of computer simulation of non-stationary heating of a fire-retardant steel column, performed using FRIEND software.

These temperatures were compared with the results of computer simulations of nonstationary heating of a fire-retardant steel column, performed using FRIEND software. To compare the simulation results with the experimental determination of the temperature of the steel column in certain places under fire conditions according to the standard temperature of the fire, we took the values of the column sample temperature № 2 (Fig. 4, curve 2), which warmed up the most.

\section{CONSTRUCTION OF MODELS OF NON-STATIONARY HEATING OF FIRE-RETARDANT STEEL COLUMN}

The computer model of the thermal state of the investigated fire-retardant column was built on the basis that the column is heated in the furnace on four sides equally. Therefore, each surface of the column is considered as a two-layer system consisting of a layer of steel and a layer of fire-retardant coating of appropriate thickness. This model allows the calculation of the temperature distribution at all spatial points of the layers over time and, in particular, at the locations of thermocouples not only by the standard temperature of the fire but also by other alternative fire modes (Fig. 5).

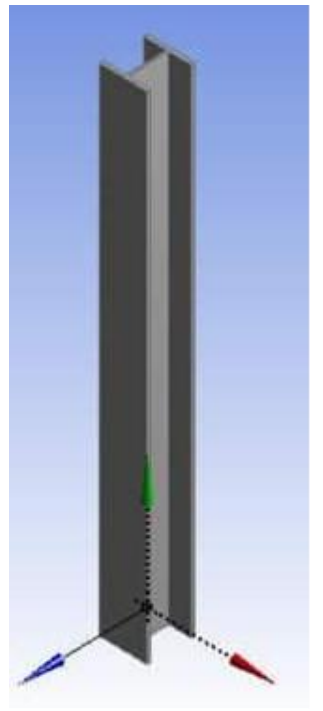

$a$

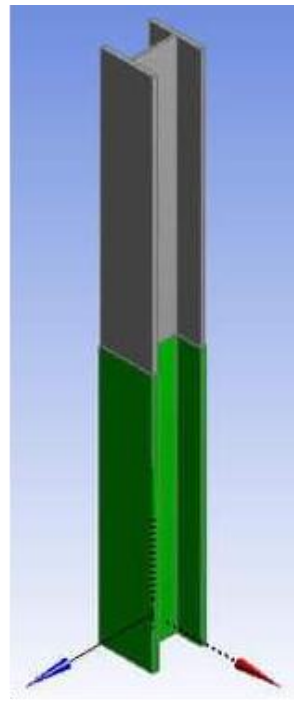

$b$

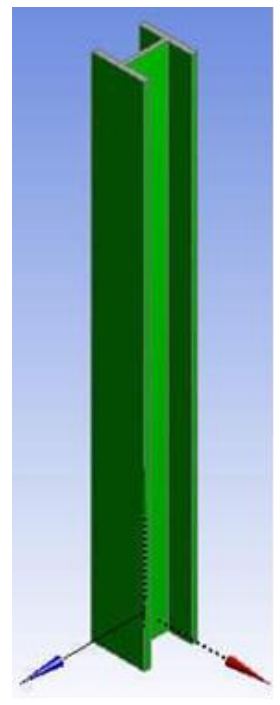

$c$

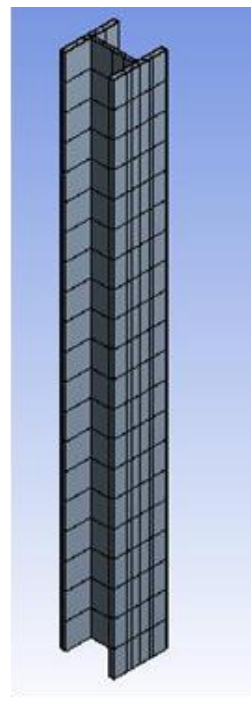

$d$

Fig. 5. Construction of geometric (a, b, c) and finite element model (d) of fire-retardant steel column 
A physical model of the system "steel structure - fire-retardant coating" has been developed (Fig. 6).

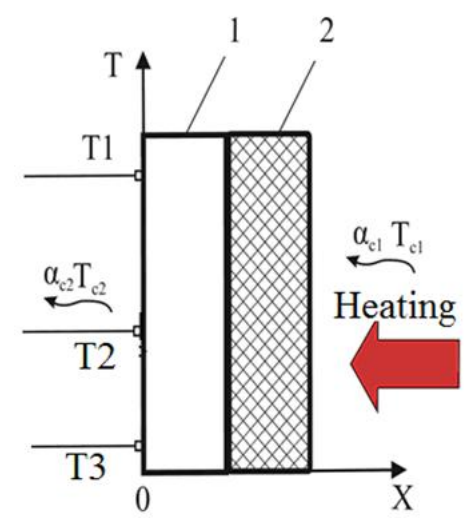

Fig. 6. Physical model of the thermal state in the system "fire-retardant coating - steel plate": 1 - steel plate; 2 - fire-retardant coating

This physical model takes into account that the heating surface of the fire-retardant coating is heated by a convective-beam mechanism from hot gases in a furnace with a temperature $\theta \mathrm{g}, \mathrm{t}$. Inside the system "fire-retardant coating - steel plate - thermal insulation" heat is transferred by thermal conductivity. The condition of ideal thermal contact between the layers of the system is accepted. From an unheated surface of thermal insulation heat exchange occurs by convection.

It is proposed to check the adequacy of the developed method for assessing the fire resistance of fire-resistant steel structures on samples of reduced size in the form of steel plates coated from one surface with a reactive flame retardant, forming a fire-retardant coating on the protected surface (Fig. 6).

\section{CHECKING THE ADEQUACY OF THE DEVELOPED METHOD FOR ASSESSING THE FIRE RESISTANCE OF FIRE-RESISTANT STEEL STRUCTURES}

Thermophysical characteristics of the investigated fire-retardant coating for use in calculations of non-stationary heating of a fire-retardant steel column were defined in [8]: thermal conductivity coefficient as a function of temperature and constant value of specific volume heat capacity $105 \mathrm{~J} / \mathrm{m}^{3} \cdot{ }^{\circ} \mathrm{C}$. Fig. 7.

The geometric dimensions of the column for modeling its thermal state are shown in
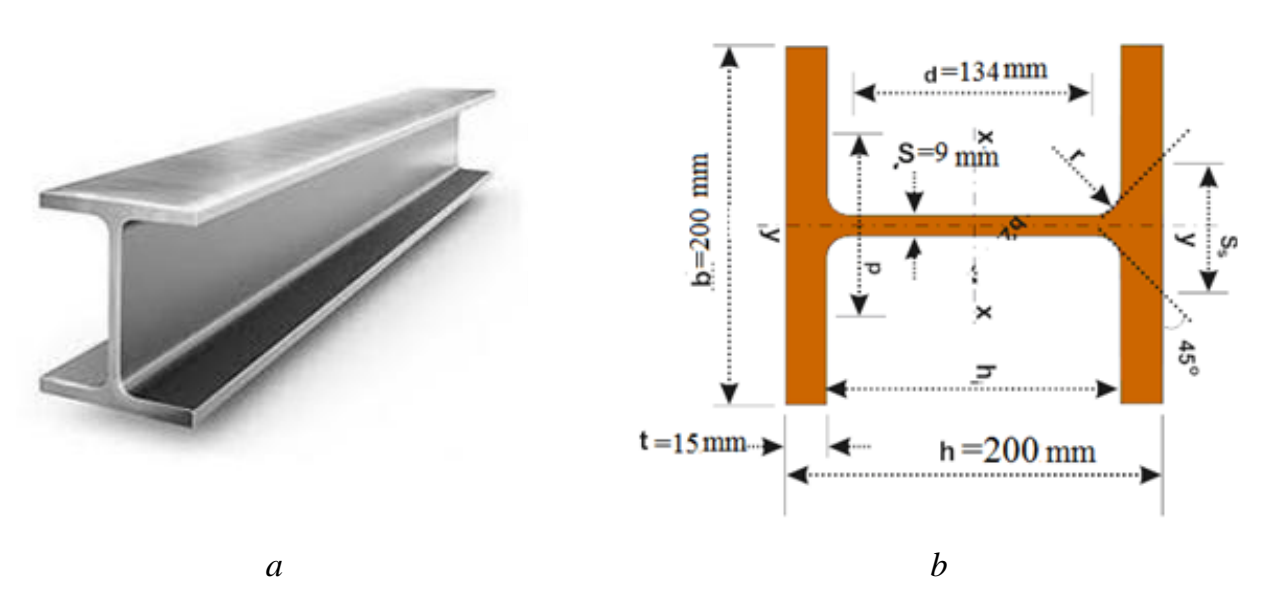

Fig. 7. Steel column: $a-$ general view; $b$ - geometric dimensions 
Thermal conductivity $\lambda_{a}$ and the specific heat of steel ca asked according to [9] and Fig. 8, 9.

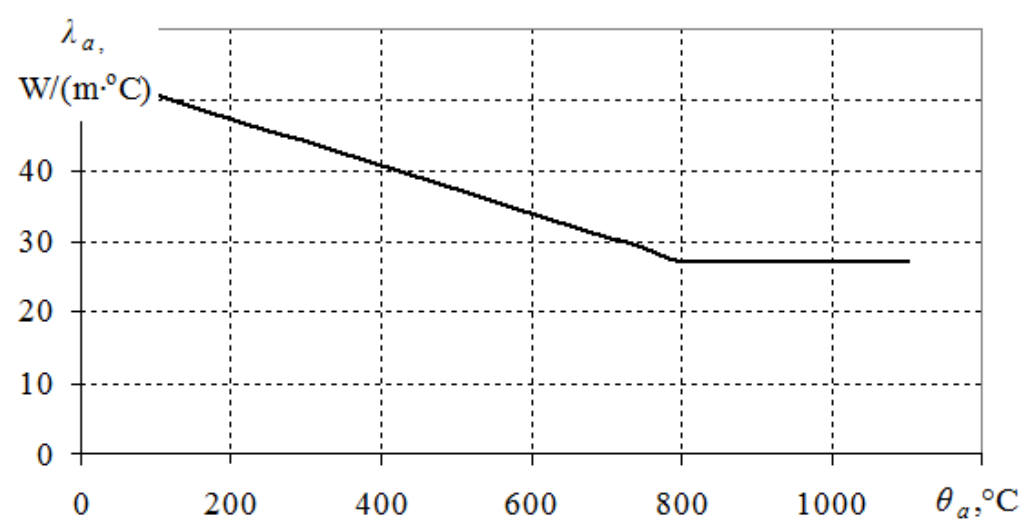

Fig. 8. Dependence of the thermal conductivity of steel on temperature

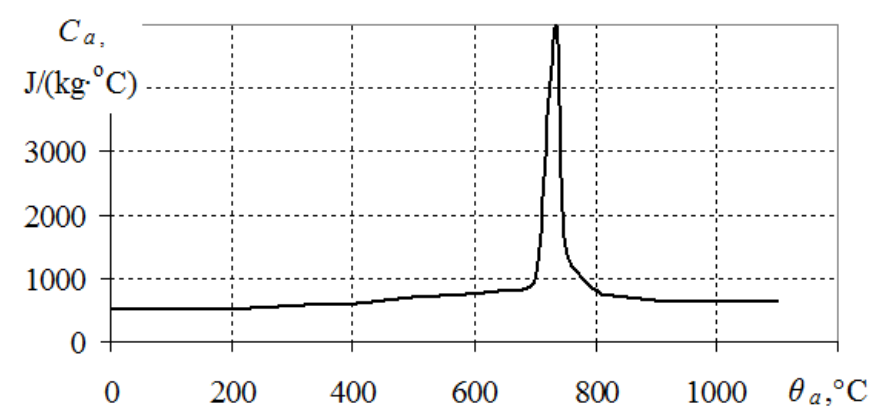

Fig. 9. Dependence of heat capacity of steel on temperature

The number of nodes of the numerical model was 15 nodes (10 nodes for steel structure and 5 nodes for fire protection coating) in spatial coordinates with a time step of $60 \mathrm{sec}$.

As a result of numerical modelling by solving direct problems of thermal conductivity, the calculated values of heating of a fire-retardant steel column were obtained, which are shown in Fig. 10.

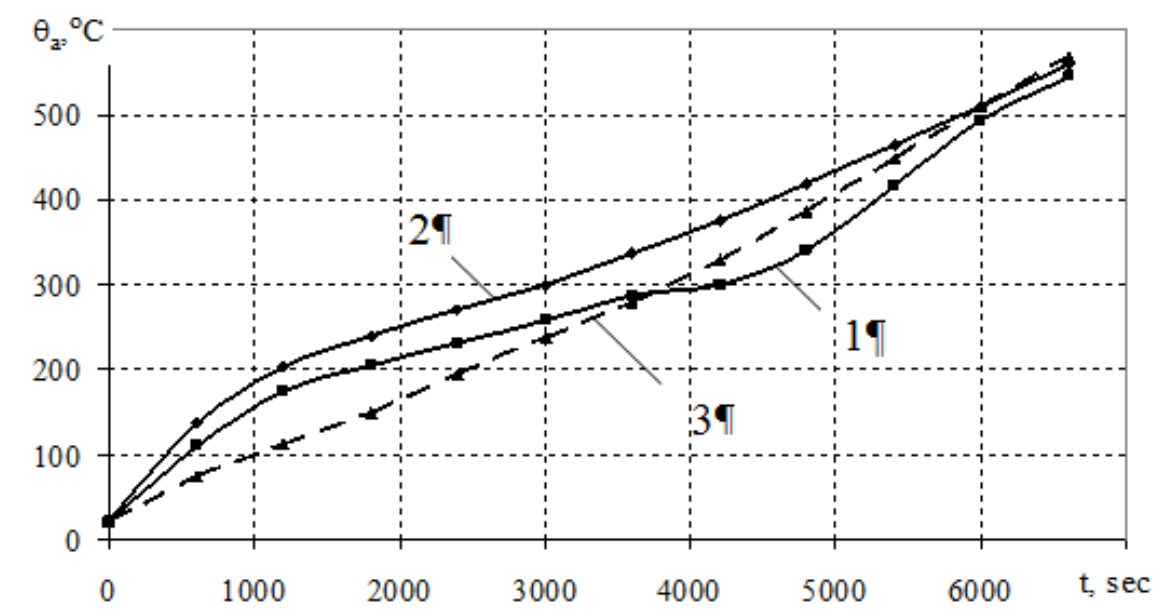

Fig. 10. Dependence of temperature of fire-protected steel columns on time of fire influence on a standard temperature mode of a fire: 1 - the experimental curve of heating of column № 1;2 - the experimental heating curve of column № 2;3 - curve calculated as a result of numerical simulation

As can be seen from Fig. 10, calculated as a result of numerical simulation, the curve of the dependence of the heating temperature of the fire-retardant steel column on the time of fire coincides with the experimental curves. It was found that the best convergence and, 
accordingly, the smallest allowable deviation range have the dependences of the column temperature №1 with the temperatures that are calculated as a result of numerical simulations. Thus, the largest error in measuring temperatures is observed at 20 minutes of calculation and is $63^{\circ} \mathrm{C}$. When comparing the results of numerical simulations with the results of tests for fire resistance of the fire-retardant column №2, such an error for 20 minutes was $92^{\circ} \mathrm{C}$. It can be concluded that when using the results of tests for fire resistance of fire-retardant steel columns at the standard temperature of the fire, it is necessary to take the average value of the test results of two steel columns. Subsequently, the results of the average values of heating of two fire-retardant steel columns were used for comparison, as shown in Fig. 11.

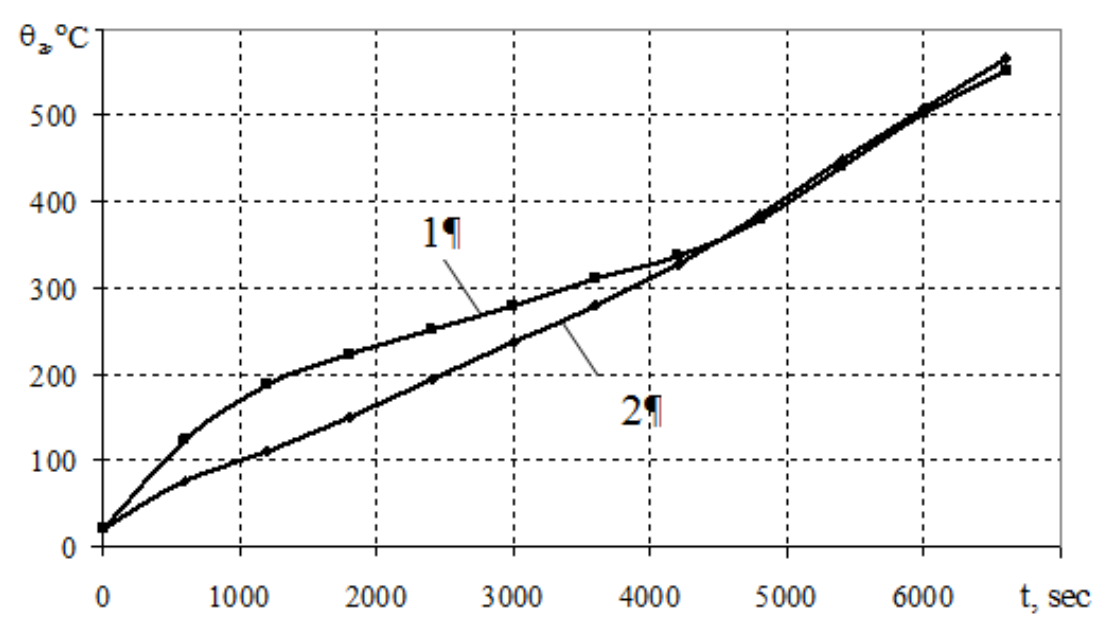

Fig. 11. Dependence of the average temperature of fire-retardant steel columns №1 and №2 on the time of fire exposure according to the standard temperature of the fire: 1 - the experimental heating curve of columns №1 and №2; 2 - curve calculated as a result of numerical simulation

From Fig. 11 it follows that the experimental curve of the average temperature values of fire-retardant steel columns №1 and №2 and the curve calculated as a result of numerical simulation have a satisfactory convergence. The results of experimental studies and numerical analysis in the FRIEND program for a time interval of 20-40 minutes differ significantly in all control points, but later this difference is stabilized, and until the end of the experiment does not exceed $10.0 \%$, which can be considered an acceptable result. All this indicates the correctness of setting the initial and boundary conditions, the construction of mathematical and physical models of thermal processes in the system "steel structure - fire-retardant coating". Ultimately, proves the efficiency of the developed method for assessing the fire resistance of fire-resistant steel structures and the adequacy of real processes that occur when heating fire-resistant steel columns without applying a load under fire conditions at standard fire temperatures.

\section{CONCLUSIONS}

1. Geometric, physical, computer and finite element models for assessing the fire resistance of fire-resistant steel structures have been developed. The peculiarity of the developed models is taking into account the thermophysical characteristics of steel structures and fire-retardant coatings that depend on temperature, as well as taking into account the peculiarities of the formation of temperature regimes of fire.

2. Based on the offered models based on the developed calculation-experimental method of estimation of fire resistance of fire-resistant steel columns of I-section without the loading applied to them is estimated.

3. It is established that the best convergence and, accordingly, the smallest allowable deviation range have the dependences of the column temperature №1 with the temperatures 
that are calculated as a result of numerical simulations. Thus, the largest error in measuring temperatures is observed at 20 minutes of calculation and is $63^{\circ} \mathrm{C}$. When comparing the results of numerical simulations with the results of tests for fire resistance of the fire-retardant column №2, such an error for 20 minutes was $92^{\circ} \mathrm{C}$. It is concluded that when using the results of tests for fire resistance of fire-retardant steel columns at the standard temperature of the fire, it is necessary to take the average value of the test results of two steel columns.

4. It is established that for the accuracy of fire resistance assessment of fire-resistant steel structures it is necessary to use the average values of temperatures of two fire-resistant steel columns. The best convergence of the results of experimental and calculated determination of the heating temperature of fire-retardant steel columns, which is not more than $10 \%$ of the allowable deviation. The efficiency of the proposed calculation and experimental method for assessing the fire resistance of fire-resistant steel structures and its adequacy to real processes in non-stationary heating of fire-resistant steel columns in the standard temperature of the fire.

\section{References}

1. Džolev, I., Radujković, A., Cvetkovska, M., Lađinović, Đ., \& Radonjanin, V. (2016, April). Fire analysis of a simply supported steel beam using Opensees and Ansys Workbench. In 4th International Conference Contemporary Achievements in Civil Engineering. Subotica. 22. 315322.

2. Li, G. Q., Han, J., Lou, G. B., Wang, Y. C. (2016). Predicting intumescent coating protected steel temperature in fire using constant thermal conductivity. Thin-Walled Structures. 98. 177-184. https://doi.org/10.1016/j.tws.2015.03.008.

3. Łukomski, M., Turkowski, P., Roszkowski, P., Papis, B. (2017). Fire Resistance of Unprotected Steel Beams-Comparison between Fire Tests and Calculation Models. In Procedia Engineering. 172. 665-672. Elsevier Ltd. https://doi.org/10.1016/j.proeng.2017.02.078.

4. Cirpici, B. K., Wang, Y. C., Rogers, B. (2016). Assessment of the thermal conductivity of intumescent coatings in fire. Fire Safety Journal. $81.74-84$. https://doi.org/10.1016/j.firesaf.2016.01.011.

5. Novak, S., Drizhd, V., Dobrostan, O., Maladyka, L. (2019). Influence of testing samples' parameters on the results of evaluating the fireprotective capability of materials. Eastern-European Journal of Enterprise Technologies. 2(10-98). 35-42. https://doi.org/10.15587/1729-4061.2019.164743.

6. De Silva, D., Bilotta, A., Nigro, E. (2019). Experimental investigation on steel elements protected with intumescent coating. Construction and Building Materials. 205. 232-244. https://doi.org/10.1016/j.conbuildmat.2019.01.223.

7. DSTU B. 1.1-17: 2007 Zakhyst vid pozhezhi. Vohnezakhysni pokryttia dlia budivelnykh nesuchykh metalevykh konstruktsii. Metod vyznachennia vohnezakhysnoi zdatnosti. [Fire protection. Fireretardant coatings for building load-bearing metal structures. Method for determining the fire retardant ability]. (ENV 13381 4: 2002, NEQ). [in Ukranian].

8. Kovalov, A., Slovinskyi, V., Udianskyi, M., Ponomarenko, I., Anszczak, M. Research of fireproof capability of coating for metal constructions using calculation-experimental method. In Materials Science Forum. 2020. Vol. 1006 MSF. 3-10.

https://doi.org/10.4028/www.scientific.net/MSF.1006.3.

9. ENV 1993-1-2:2005. Eurocode 3. Design of steel structures. Part 1.2, general rules - Structural fire design. The European Union Per Regulation 305/2011. Directive 98/34/EC. Directive 2004/18/EC.

\section{Література}

1. Džolev, I., Radujković, A., Cvetkovska, M., Lađinović, Đ., Radonjanin, V. Fire analysis of a simply supported steel beam using Opensees and Ansys Workbench. In 4th International Conference Contemporary Achievements in Civil Engineering, Subotica. 2016. Vol. 22. P. 315322. 
2. Li, G. Q., Han, J., Lou, G. B., Wang, Y. C. Predicting intumescent coating protected steel temperature in fire using constant thermal conductivity. Thin-Walled Structures. 2016. Vol 98. P. $177-184$.

3. Łukomski, M., Turkowski, P., Roszkowski, P., Papis, B. Fire Resistance of Unprotected Steel Beams-Comparison between Fire Tests and Calculation Models. In Procedia Engineering. 2017. Vol. 172. P. 665-672. Elsevier Ltd.

4. Cirpici, B. K., Wang, Y. C., Rogers, B. Assessment of the thermal conductivity of intumescent coatings in fire. Fire Safety Journal. 2016. Vol. 81. P. 74-84.

5. Novak, S., Drizhd, V., Dobrostan, O., Maladyka. Influence of testing samples' parameters on the results of evaluating the fireprotective capability of materials. Eastern-European Journal of Enterprise Technologies. 2019. Vol. 2(10-98). P. 35-42.

6. De Silva, D., Bilotta, A., Nigro, E. Experimental investigation on steel elements protected with intumescent coating. Construction and Building Materials. 2019. Vol. 205. P. 232-244.

7. ДСТУ Б В 1.1-17:2007 Захист від пожежі. Вогнезахисні покриття для будівельних несучих металевих конструкцій. Метод визначення вогнезахисної здатності. [Чинний від 2008-0101], 2009. $105 \mathrm{c}$.

8. Kovalov, A., Slovinskyi, V., Udianskyi, M., Ponomarenko, I., Anszczak, M. Research of fireproof capability of coating for metal constructions using calculation-experimental method. In Materials Science Forum. 2020. Vol. 1006 MSF. P. 3-10.

9. ENV 1993-1-2:2005. Eurocode 3, Design of steel structures, Part 1.2, general rules - Structural fire design. The European Union Per Regulation 305/2011. Directive 98/34/EC. Directive 2004/18/EC81 p.

\author{
Andrii Kovalov \\ National University of Civil Defence of Ukraine \\ Ph.D., Senior Research \\ Chernyshevska str., 94, Kharkiv, Ukraine, 61023 \\ kovalev27051980@gmail.com \\ ORCID 0000-0002-6525-7558 \\ Yurii Otrosh \\ National University of Civil Defence of Ukraine \\ Doctor of Technical Sciences, Professor \\ Chernyshevska str., 94, Kharkiv, Ukraine, 61023 \\ yuriyotrosh@gmail.com \\ ORCID 0000-0003-0698-2888 \\ Vitalii Tomenko \\ Cherkasy Institute of Fire Safety of National University of Civil Defence of Ukraine \\ Ph.D., Associate Professor \\ Onoprienka str., 8 Cherkasy, Ukraine, 18034 \\ firech1996@gmail.com \\ ORCID 0000-0001-7139-9141 \\ Vitaliy Slovinskyi \\ Cherkasy Scientific Research Forensic Centre of the Ministry of Internal Affairs in Ukraine \\ Ph.D. \\ Pasterovska str., 104 Cherkasy, Ukraine, 18000 \\ vetal130971@ukr.net \\ ORCID 0000-0002-6194-3171
}

For references:

Kovalov A., Otrosh Y., Tomenko V., Slovinskyi V. (2021). Evaluation of fire resistance of fire protected steel structures by calculation and experimental method. Mechanics and Mathematical Methods. 3 (2). 29 - 39

\title{
Для посилань:
}

Ковальов А. І., Отрош Ю. А., Томенко В. І., Словінський В. К. Оцінювання вогнестійкості

вогнезахищених сталевих конструкцій розрахунково-експериментальним методом. Механіка та математичні методи, 2021. Т. 3. №. 2. С. 29-39. 